\title{
OTONOMI DESA DALAM PENGELOLA KEUANGAN BERDASARKAN UNDANG-UNDANG NO 6 TAHUN 2014
}

\author{
Oleh : \\ I Wayan Wisadnya, SH, MH \\ Program Studi, Fakultas Hukum Universitas Mahendradatta \\ Jl. Ken Arok No. 12 , Peguyangan Denpasar Utara, Bali 80115. \\ (wisadnyarena@gmail.com)
}

\begin{abstract}
Abstrak, Desa adalah sebagai suatu bentuk pemerintahan terendah yang otonom, supaya dapat melaksanakan otonomi dengan baik, maka penyelenggaraan pemerintahannya harus memiliki faktor utama yang dikatakan berotonomi adalah faktor Sumber daya Manusia sebagai pelaksananya, faktor Keuangan, Faktor Sarana dan Prasarana penunjang serta Kelembagaan.Pemerintah desa yang keberadaannya berhubungan langsung dengan masyarakat dan sebgai ujung tombak pembangunan, maka pemerintah desa semakin dituntut kesiapannya baik dalam hal merumuskan kebijakan desa ( dalam bentuk peraturan desa),merencanakan pembanguan desa yang disesuaikan dengan situasi kondisi serta dalam memberikan pelayanan rutin kepada msyarakat.Desa sebagai daerah otonom harus memiliki kewenangan dan kemampuan untuk menggali sumber keuangan atau pendapatan, mngelola dan menggunakan keuangan sendiri, dengan kata lain adanya kemandirian atau otonomi desa dalam mengelola anggaran dan pendapatan belanja desa Pengelolaan keuangan desa menyangkut kekayaan desa,Penyusunan anggaran pendapatan dan belanja Desa,pengadministrasian atau penata usahaan keuangan dan pertanggungjawaban keuangan. Adapunpermasalahan dalam penelitian ini, adalah apakah UU Desa sudah memberikan otonomi terhadap keuangan desa, serta pelaksanan kewenangan pemerintah desa dalam mewujudkan otonomi desa.? Penelitian ini merupakan penelitian dengan menggunakan methode penelitian Yuridis Normatif, dengan menggunakan bahan-bahan hukum, yaitu pendekatan perundang-undangan dan pendekatan konseptual,adalah analisis normatif memperlihatkan bahwa kewenangan pemerintah desa didasarkan pada asas-asas dan norma-norma hukum yang berlaku, sedangkan konseptual otonomi pengelolaan keuangan desa.
\end{abstract}

Kata kunci : Kewenangan, Otonomi desa, Keuangan Desa.

Abstract, Village is as the lowest form of autonomous government, so that it can implement autonomy properly, then the administration of its government must have the main factor that is said to be autonomous is the Human Resources factor as the executor, Financial factor, Supporting Infrastructure and Institutional Factors and Institution. Village Government whose existence is directly related to the community and as the spearhead of development, the village government is increasingly required to be prepared both in terms of formulating village policies (in the form of village regulations), planning village development that is adapted to the situation conditions and in providing routine services to the community. autonomous people must have the authority and ability to explore financial or revenue sources, manage and use their own finances, in other words there is independence or village autonomy in managing village budget and expenditure expenditure. which is the village's wealth, the compilation of the village's income and expenditure budget, the administration or administration of financial affairs and financial accountability. The problem in this research is whether the Village Law has given autonomy to village finances, as well as the exercise of authority of the village government in realizing village autonomy. This research is a study using Normative Juridical research methods, using legal materials, namely the legislative approach and conceptual approach, is a normative analysis showing that the authority of the village government is based on the principles and legal norms that apply, while the conceptual village financial management autonomy.

Keywords: Authority, Village Autonomy, Village Finance. 


\section{PENDAHULUAN}

1. Latar belakang masalah

Di dalam Ketentuan Undang-Undang Dasar Negara Republik Indonesia tahun 1945 pasal I ayat (3) telah di amanatkan : bahwa Indonesia adalah Negara berdasarkan hukum (Rechtsstaat ) tidak berdasar kekuasaan belaka ( Mahchtsstaat ) Negara Hukum mengisyarakan, Indonesia mempunyai citacita hukum ( Rechtsidee) untuk mengusai hukum dasar, baik tertulis maupun tidak. Rechtsidee adalah tujuan hukum, sebagai yang diuraikan pada alenia ( IV ) Pembukan UUD 1945, yaitu Terciptanya ketertiban, keamanan, kemerdekaan, keadilan dan kesejahtraan bangsa Indonesia.

Dengan demikian dalam kehidupan bermasyarakat diperlukan suatu sistem hukum untuk menciptakan kehidupan yang harmonis, demokratis, dan teratur, sehingga Rechtsidee sebagai yang dimaksud alenia IV ( empat) Pembukaan UUD 1945 dapat tercapai.

Sistem Pemerintahan di Indonesia sebagaimana dituangkan dalam UUD Tahun 1945 dalam penjelasan dinyatakan bahwa daerah Indonesia akan dibagi dalam daerah Provinsi, dan daerah Provinsi akan dibagi pula dalam daerah yang lebih kecil.

Di daerah yang bersifat otonom (streeken locale rechts gemeenschappen) atau bersifat daerah administrative belaka, semuanya menurut aturan yang akan ditetapkan dengan Undang-undang.

Di daerah-derah yang bersifat Otonom akan diadakan Badan Perwakilan Daerah oleh karena itu di daerah pun, pemerintah yang akan bersendikan atas dasar permusyawaratan.
Keadaan ini adalah untuk memunculkan kembali asli masyarakat yang selalu mengedepankan musyawarah mufakat dalam segala pengambilan keputusan.

Permusyawaratan merupakan inti dalam kehidupan berbangsa dan bernegara bagi seluruh rakyat Indonesia.

Dengan perkembangan Era Globalisasi, demokratisasi, dan Transparansi, maka penyelenggaraan Pemerintahan tidak akan terlepas dari pengaruh global. Oleh karena itu prinsip demokrasi, pemerataan dan keadilan menuntut adanya pemberian peran serta kepada warga negara dalam sistem pemerintahan. jadi yang paling essensial dalam penyelenggaraan Pemerintah Daerah bersifat Otonom adalah pemberian kewenangan yang seluas luasnya kepada daerah di sertai hak dan kewajiban tertentu.

Berdasarkan uraian latar belakang yang telah diuraikan diatas maka dirumuskan permasalahan sebagai berikut : Apakah Undang-Undang Desa No 6 Tahun 2014 Tentang Desa Sudah Memberikan Otonomi Tentang Pengelolaan Keuangan Desa ? Dalam penulisan ini adapun methode yang akan dipergunakan adalah dengan methode pendekatan yang bersifat Yuridis Normatif.

\section{PEMBAHASAN}

1. Pengertian Desa

Desa adalah kesatuan masyarakat hukum yang memiliki kewenangan untuk mengurus rumah tangganya berdasarkan hak asal usul dan adat istiadat yang diakui dalam 
pemerintahan Nasional dan berada di daerah Kabupaten.

Desa menurut H.A.W Widjaja dalam bukunya yang berjudul "Otonomi Desa" Menyatakan bahwa Desa adalah sebagai kesatuan masyarakat hukum yang mempunyai susunan asli berdasarkan hak asal usul yang bersifat istimewa. ( H.A.W. Widjaja, 2003, Pemeintahan Desal Marga, Raja Grafindo Persada,Jkt h. 3 ).

Berdasarkan tinjauan geografi menurut R Bintarto, Desa merupakan suatu hasil perwujudan geografis, social, politik,dan cultural yang terdapat disuatu daerah serta memiliki hubungan timbal balik dengan daerah lain. ( R. Bintaro, 1989, Dalam Interaksi DesaKota Dan Permasalahannya, Ghalia Indonesia, $J k t, h 2$ ).

Sedangkan Pengertian tentang Desa menurut Undang-undang adalah :

a. Peraturan Pemerintah Nomor 72 tahun 2005 Tentang Desa Pasal 1 (7) Desa atau yang disebut dengan nama lain, selanjutnya disebut Desa, adalah Kesatuan masyarakat hukum yang memiliki batas-batas wilayah yan berwenang untuk mengatur kepentingan masyarakat setempat, berdsarkan asal usulndan adat istiadat setempat yang diakui dan dihormati dalam sistem pemerintahan Negara Kesatuan Republik Indonesia.

b. Peraturan Pemerintah Nomer 43 Tahun 2014 Tentang Peraturan Pelaksanaan Undang-undang No 6 tahun 2014 pasal 1, adalah Desa dan Desa adat atau yang disebut dengan nama lain, selanjutnya disebut Desa
, adalah kesatuan masyarakat hukum yang memilki batas wilayah yang berwenang untuk mengatur dan mengurus urusan pemerintahan, kepentingan masyarakat setempat berdasarkan prakarsa masyarakat, hak asal usul,dan/atau hak tradisional yang diakui dan dihormati dalam system Pemerintahan Negara Kesatuan Republik Indonesia.

c. Undang -undang No 23 Tahun 2014 Tentang Pemerintah Daerah Pasal 1 Desa adalah Desa dan Adat atau yang disebut dengan nama lain, Selanjutnya disebut Desa adalah kesatuan masyarakat hukum yang memiliki batas wilayah yang berwenang untuk mengatur dan mengurus urusan Pemerintahan, kepentingan masyarakat setempat berdasarkan prakarsa masyarakat, hak asal usul, dan/atau hak tradisional yang diakui dan diihormati dalam system pemerintahan Negara Kesatuan Republik Indonesia.

d. Undang-undang Nomor 6 Tahun 2014 Tentang Desa Pasal 1, Desa adalah Desa dan adat atau yang disebut dengan nama lain, selanjutnya disebu Desa adalah kesatuan masyarakat hukum yang memiliki batas wilayah yang berwenang untuk mengatur dan mengurus urusan pemerintahan, kepentingan masyarakat setempat berdasarkan prakarsa masyarakat, hak asal usul dan/atau hak tradisional yang diakui dan dihormati dalm system pemerintahan Negara Republik Indonesia 
Pengertian Desa menurut UndangUndang No 6 Tahun 2014 dijelaskan bahwa "Desa dan Adat atau yang disebut dengan nama lain, selanjutnya disebut desa adalah kesatuan masyarakat hukum yang memiliki batas wilayah yang berwenang untuk mengatur dan mengurus urusan pemerintahan, kepentingan masyarakat setempat berdasarkan prakarsa masyarakat, hal asal-usul dana tau hak tradisional yang diakui dan dihormati dalam sistem pemerintahan Negara Republik Indonesia”.

Mengingat pentingnya kedudukan desa dalam menyelenggarakan pemerintahan desa, maka dalam penyusunan peraturan desa tersebut harus didasarkan kepada kebutuhan dan kondisi desa setempat, mengacu kepada peraturan per-undang-undangan yang lebih tinggi, serta tidak boleh merugikan kepentingan umum. Lebih dari pada itu, produk politik harus disusun secara demokratis dan partisipatif.

\section{Otonomi Desa}

Undang-undang Nomor 32 tahun 2004 Tentang Pemerintahan Desa yang meletakkan posisi desa yang berada dibawah Kabupaten tidak koheren dan konkruen dengan nafas lain dalam Undang-undang diatas, yang justru mengakui dan menghormabti kewenangan asli yang berasal hak asal usul. Pengakuan pada kewenangan asal usul ini menunjukan bahwa UU. NO : 32 Tahun 2004 menganut prinsip pengakuan (rekognisi). Konskwensi dari pengakuan atas Otonomi asli adalah ; Desa memiliki hak mengatur dan mengurus rumah tangganya sndiri berdasarkan asal usul dan adat istiadat setempat (Self governing community), dan bukan merupakan kewenangan yang diserahkan pemerintah atasan pada desa.Berdasarkan penjelasan peraturan pemerintah Nomor 72 Tahun 2005 Tentang Desa , Menyatakan bahwa Otonomi asli, memiliki makna bahwa kewenangan pemerintah desa dalam mengatur dan mengurus masyarakat setempat didasarkan pada hak asal usul dan niali-nilai social budaya yang terdapat pada masyarakat setempat namun harus diselenggarakan dalam perspektif administrasi pemerintahan negraa yang selalu mengikuti perkembangan zaman.

Undang-undang Nomer 8 Tahun 2005 Tentang Perubahan atas UU No 32 Tahun 2004 Tentang Pemerintahan Daerah mengakui adanya Otonomi yang dimiliki oleh desa dan kepada desa dapat diberikan penugasan ataupun pendelegasian dari pemerintah ataupun Pemerintah Daerah untuk melaksanakan urusan pemerintah tertentu.Dengan demikian, urusan pemerintah menjadi kewenangan desa mencakup urusan pemerintahan yang sudah ada berdasarkan hak asal usul desa, urusan pemerintah yang menjadi kewenangan kabupaten /kota yang dserahkan pengaturannya kepada desa,tugas pembantuan dari pemerintah dan pemerintah daerah, urusan pemerintah lainnya yang oleh peraturan perundangundangan yang diserahkan kepada desa. Otonomi Desa merupakan otonomi asli, bulat dan utuh serta bukan merupakan pemberian dari pemerintah. Sebaliknya pemerintah berkewajiban menghormati otonomi asli yang 
dimiliki oleh desa tersebut. Sebagai kesatuan masyarakat hukum yang mempunyai susunan asli berdasarkan hak istimewa, desa dapat melakukan perbuatan hukum, baik hukum public maupun hukum perdata, memiliki kekayaan, harta benda serta dapat dituntut dan menuntut dimuka pengadilan.

Sebagai wujud demokrasi, didesa dibentuk Badan Perwakilan desa yang berfungsi sebagai Lembaga Legislatif dan Pengawasan terhadap pelaksanaan peraturan desa, Angaran Pendapatan dan Belanja Desa. Untuk itu, Kepala desa dengan persetujuan Badan Perwakilan Desa mempnyai kewenangan untuk melakukan perbuatan hukum dan engadakan perjanjian yang saling menguntungkan dengan pihak lain, menetapkan sumber-sumber pendapatan desa menerima sumbangan dari pihak ketiga dan melakukan perjanjian desa.

Sejak berlakunya Undang-undang N0 32 Tahun 2004 sebagaimana telah diubah dengan Undang-undang No 23 Tahun 2014 tentang Pemerintahan Daerah, Implementasi kebijakan Otonomi daerah menjadi focus pemerintah pusat dan Daerah. Disamping menempatkan Provinsi dan Kabupaten/kota sebagai sasaran pelaksanaan otonnomi, pemerintah juga memandang bahwa Desa sudah saatnya melaksanakan otonominya selain otonomi asli yang ada selama ini. Sistem pelaksanaan otonomi daerah di Indonesia menganutu sistem otonomi bertingkat, yakni Provinsi memiliki otonomi terbatas, Kabupaten /kota memiliki otonomi luas dan desa memiliki otonomi asli.
Undang-undang No 23 Tahun 2014 Tentang Pemerintahan Desa, Pasal 200 dan Pasal 216 menyatakan bahwa; Desa di Kabupaten /Kota memiliki kewenangan yang dapat diatur secara bersama antara Pemerintah Desa dan Badan Perwakilan Desa yang dimaksudkan untuk meningkatkan pelayanan kepada masyarakat. Penyelenggaaan desa yang otonom dengan kewajiban yang dilimpahkan tersebut pada dasarnya merupakan proses yang terjadi secara simultan dan berkesinambungan yang memerlukan pengetahuan aparatur daerah tentang kewenangan mereka, potensi daerah dan menjaring aspirasi masyarakat di Wilayahnya.

Kebijakan Otonomi Daerah juga berimplikasi terhadap sistem administrasi Pemerintahan Desa. Artinya Kedudukan Desa sebagai subsistem pemerintahan terendah dalam sistem pemerintahan Nasional di Indonesia memerlukan adaptasi dan antisipasi perkembangan tersebut.

Salah satu prinsip penyelenggaraan otonomi daerah yang perlu mendapat perhatian dalam hal ini adalah partusipasi masyarakat dalam penyelenggaraan pemerintahan, khususnya di tingkat Desa.

\section{Otonomi Anggaran}

Perubahan bentuk otonomi daerah dalam era reformasi ini ditandai dengan pelaksanaan UU No 22 Tahun 1999 Tentang Pemerintahan Daerah dan UU No 25 Tahun 1999 Tentang Perimbangan Keuangan antara Pemerintah pusat ddan Daerah. Sejak awal 2001 sampai oktober 2004. Kemudian kedua UU ini digantikan dengan UU No 32 Tahun 2004 
Tentang Pemerintahan Daerah dan UU No 33

Tahun 2004 Tentang Perimbangan Keuangan

antara Pemerintah pusat dan Pemerintah

Daerah

Dalam Pasal 5 UU N0 32 Tahun 2004. Menyebutkan bahwa: Otonomi Daerah adalah hak, wewenang, dan keawjiban daerfah otonomi untuk mengatur dan mengurus sendiri urusan pemerintahan dan kepentingan masyarakat setempat sesuai dengan peraturan Per-undang-undangan. Pemerintah Daerah dalam upaya menyelenggarakan pelayanan sampai ketngkat paling bawah dan langsung bersinggungan dengan masyarakat maka dibentuk desa atau dengan nama lain untuk menjalankan pemerintahan tingkat desa. Juga dalam Pasal 1 angka 12 UU N0 32 Tahun 2004 disebutkan bahwa "Desa atau yang disebut dengan nama lain, selanjutnya disebut desa, adalah kesatuan msayarakat hukum yang memiliki batas batas wilayah yang berwenang untuk mengatur dan mengurus kepentingan masyarakat setempat, berdasarkan asal usul dan adat istiadat setempat yang diakui dan dihormati dalam sistem Pemerintahan Negara Republik Indonesia”.

Pemerintahan Desa sebagai suatu bentuk pemerintahan terendah yang Otonom, agar dapat melaksanakan Otonomi dengan baik, maka penyelenggaraan Pemerintahannya harus memiliki faktor utama yang dikatakan ber otonomi adalah faktor Sumber daya manusia sebagai pelaksanaanya, faktor Keuangan, faktor saran dan prasarana penunjang serta kelembagaan.

Salah satu faktor yang sangat penting dalam penyelenggaraan otonomi tersebut adalah faktor keuangan, karena penyelengaraan pemeritah desa memerlukan biaya untuk melaksanakan tugas-tugas pemerintahan, pembangunan dan pelayanan masyarakat. Semakin besar jumlah uang yang dimiliki desa semakin banyak pula kegiatan yang dapat dilaksanakan. Desa sebagai daerah otonom harus memiliki kewenangan dan kemampuan untuk menggali sumber keuangan atau pendapatan, mengelola dan menggunakan keuangan sendiri, dengan kata lain adanya kemandirian atau otonomi desa dalam mengelola anggaran dan pendapatan dan belanja desa.

Adapun Otonomi yang tumbuh di desa adalah otonomi yang bersifat asli yang berakar dalam budaya masyarakat sebagi suatu persekutuan masyarakat hukum. Sementara tujuan dari program pembangunan desa adalah upaya meningkatkan kesejahtraan masyarakat desa, mempercepat kemajuan kegiatan ekonomi pedesaan yang berkeadilan, dan mempercepat industrialissi desa.

Hal ini menurut Hanif Nurcolish dapat menciptakan lapangan kerja, membuka peluang tersedianya bahan pangan dan bahan lainnya agar menunjang kebutuhan komsumsi dan produksi, terwujudnya keterkaitan ekonomi local, dan meningkatnya kapsitas lembaga serta organisasi ekonomi masyarakat desa (Nurcholis, hanif, 2011, Pertumbuhan dan Penyelenggaraan pemerintah desa, Semarang, Erlangga, h9)

4. Pengelolaan Keuangan Desa

Secara umum sistem pengelolaan keuangan desa dan Anggaran pendapatan 
dan Belanja Desa (APBDes) di jelaskan dalam UU No 32 Tahun 2004 Pasal 212 sebagai berikut:

1. Keuangan desa adalah semua hak dan kewajiban desa yang dapat dinilai dengan uang, serta segala sesuatu baik berupa uang maupun barang yang dapat dinilai ddijadikan milik desa dengan pelaksanaan hak dan kewajiban.

2. Hak dan Kewajiban sebagaimana ayat (1) menimbulkan pendapatan, belanja dan pengelolaan keuangan desa.

3. Sumber pendapatan desa sebagai mana dimaksud pada (2) terdiri atas:

a. Pendapatan asli desa:

b. Bagi hasil pajak daerah dan retribusi daerah kabupaten/kota

c. Bagian dari dana perimbangan keuangan pusat dan daerah yang diterima kabupaten/kota

d. Bantuan dari pemerintah, pemeintah propinsi, dan pemerintah kabupaten/kota

e. Hibah sumbangan dari pihak ketiga.

Dalam Peraturan Menteri Dalam Negeri No 37 Tahun 2007 Tentang Pedoman pengelolaan Keuangan Desa, dimaksudkan untu memudahkan desa dalam pelaksanaan pengelolaan keuangannya, dan harapan lainnya pemerintah desa dapat dikelola dengan baik oleh siapa saja yang diberi amanat untuk menjalankannya. Ini sangat membantu, karena permendagri tersebut telah diatur proses dan mekanisme APBDes tentang siapa yang bertanggung jawab, dan bagaimana cara pertanggung jawabannya.
Pada umumnya desa mempunyai sumbersumber keuangan yang relative tetap, Brata kusumah dan Solihin mengemukakan tentang bebebrapa sumber tersebut seperti:

a. Pendapatan asli desa (hasil-hasil usaha desa, hasil kekayaan desa, swadaya dan partisipasi masyaakat, gotong-royong dan lain-lain)

b. Bantuan dari pemerintah dan pemerintah daerah.

c. Pendapat lain-lain yang sah.

d. Sumbangan dari pihak ketiga,

e. Pinjaman jasa. (Brata kusumah, DS dan Solihin, 2001, Otonomi Penyelenggara Pemerintah Daerah, Jakarta, Gramedia pustaka utama, $h, 9)$

5. Otonomi Pengelolaan Keuangan Desa

Otonomi pengelolaan keuangan desa terekspresi dalam anggaran, anggaran kadangkadang disusun hanya sebagai kegiatan rutin dari pemerintah desa, aau hanya sebagai formalitas dri permintaan bantuan pembangunan kabupaten atau pemerintah pusat. Hal tersebut tentunya menjadi salah satu sisi untuk melihat kemampuan desa dalam mendapatkan dana dan mengalokasikannya secara berkesinambungan. Adapun Otonomi pengelolaan keuangan desa meliputi:

1. Otonomi sumber pendapatan Desa.

2. Potensi sumber daya alam Desa

3. Penyusunan Anggaran Pendapatan dan Belanja Desa.

4. Otonomi Pelaksanaan Pengelolaan APBDes.

\section{PENUTUP}

1. Simpulan 
Bahwa Undang-undang telah memberikan Otonomi kepada pemerintahan Desa, baik dalam pengelolaan keuangan, sumber dana dan asal usul desa. Dari sekian banyak yang telah dikeluarkan oleh pemerintah tentang Desa, Sejak Indonesia Merdeka Tgl 17 Agustus 1945 memang UU No 6 Tahun 2014 tentang Desa adalah yang paling baik, Desa sebagai ujung tombak pemerintahan terbawah memiliki otonomi dalam mengatur pembangunan untuk mensejahterakan rakyatnya. akan tetapi dalam pelaksanaannya harus diawasi agar tidak terjadi penyimpangan dan penyalah gunaan wewenang. Kemudian Pemerintahan desa harus bisa menjalankan tugas dan fungsinya sesuai amanat Undangundang agar tidak terjebak dalam jeratan hukum. Disamping itu Masyarakat desa diharapkan juga ikut mengawasi dan mengambil peran aktif melalui musyawarah desa agar pelaksanaan pembangunan, melalui pengelolaan Keuangan desa bisa benar-benar efektif dan tepat sasaran serta dilakukan secara transparan dan akuntebel.

2. Saran

Pemerintahan Desa disarankan untuk semakin memperkuat dan meningkatkan Sumber daya Manusia (SDM) yang lebih berkualitas, Profesional, dan proporsional, serta Akuntabel dalam pengelolaan Keuangan desa, dan pelaksanaan kewenangan desa dalam mewujudkan otonomi desa. Selanjutnya Pemerintahan Desa tetap mengadakan koordinasi dengan Pemerintah Kabupaten /kota, sehingga terjadi senergitas dalam mengimplementasikan suatu peraturan atau
Per-Undang- undangan, sampai ke Pemerintahan yang paling bawah, yaitu Desa.

\section{DAFTAR BACAAN}

BUKU :

Bambang Yudoyono,2000, Makalah Kritis Implementasi UU No: 22 Tahun 1999 : Upaya Mencegah Disintegrasi bangsa,disampaikan pada seminar dalam rangka kongres ISMAHI, Bengkulu, 22 Mei 2000

Bewa ragawino,2003, Desentralalisasi dalam rangka Otonomi Daerah di Indonesia, unpad, Bandung.

Bintaro,R, 1989,Dalam Interaksi Desa kota dan Pemasalahannya, Ghalia Indonesia,Jakarta.

Brata kusumah,DS Dan Solihin, 2001, Otonomi Penyelenggara Pemerintah Daerah, Jakarta, Gramedia Pustaka Utama.

H.A.W. Widjaya, 2003,Pemerintahan Desa/Marga,Raja Grafindo, Jakarta.

Nurcholis,Hanif,2011,Pertumbuhan dan Penyelenggaraan Pemerintah Desa,Semarang,Erlangga,

Pardjoko,2002, Filsafat Otonomi Daerah Dikaitkan Dengan Pelaksanaan UU NO 22 Tahun 1999, UU No 25 Tahun 1999, makalah Falsafah sains, Progra Pasca Sarjana /S3 IPB.

Sadu Wasistion,2003 Delema Upaya Effisiensi Birokasi Daerah,CLGI,Jatinangor

Setyo Pamungkas ,2010,Investasi di Era Otonomi Daerah,MIH UKSW.

Siswanto Sunarno,2006, Hukum Pemerintahan DiDaerah diIndonesia,Sinargrafika, Jakarta. 
Raad Kertha, Vol. 02, No. 02 Agustus 2019 - Januari 2020

Soetidjo,1990, Hubungan Pemerintah Pusat

dan Daerah, RinekaCiptaJakarta.

Syaukani,2001,Menatapharapan Masa Depan

Otonomi Daerah,Gerbang Dayaku,Kaltim.

PER-UNDANG-UNDANGAN

1. Undang-undang Nomor 6 Tahun 2014

Tentang Desa
2. Undang-undang Nomor 32 Tahun 2004 Tentang Pemerintahan Daerah.

3. Undang-undang Nomor 23 Tahun 2014 Tentang Pemerintahan Daerah.

4. Perturan Pemerintah Nomor 43 Tahun 2014 Peraturan Pelaksana Desa

5. Peraturan Pemerintah Nomor 72 Tahun 2005 Tentang Desa 